\title{
A vocação pedagógica dos museus de Filadélfia'
}

\author{
Roberto Carvalho de M agalhães*
}

Resumo: A ação educativa dos museus deFiladélfia éextraordinariamenteampla. D os museus menores, como o Benjamin Franklin U nderground M useum, ao imenso Philadelphia M useum of Art, eles oferecem um leque vasto ediversificado de materiais pedagógicos, seja dirigidosà escola, seja ao público em geral. Este ensaio relata e analisa as suas estratégias educativas, especial mente as ações educativas dos museus dearte.

Palavras-chave: museus; arte; ação educativa.

The educational vocation of the Philadelphia museums Abstract: Theeducational action of thePhiladel phia M useumsisextraordinarily vast. From the smaller museums, as the Benjamin Franklin Underground M useum, to the immense Philadel phia M useum of Art, they offer an ampleand varied range of pedagogical materials, both for schools and for the public in general. Thisessay reportsand analyzes their educational strategies, especially the educational actions of the art museums.

Key words: museums; art; educational action.

Um pequeno detalhe pode deflagrar uma grande experiência - assim como pode impedi-la.

"ABAIXAM OS AS LUZES para proteger os objetos expostos. Uma iluminação intensa demais enfraqueceria estes manufatos frágeis. $O$ s seus ol hos adaptar-se-ão à luz mais fraca em um ou dois minutos". N este aviso claro e conciso, está contido um dos princípios que regem os museus de Filadélfia e, por exten-

\footnotetext{
* Docente de História da Arte e Museologia, Università Internazionale dell'Arte, Florença, Itália. Recentemente, curador da exposição A Arte do Mito e co-curador da exposição Virtude e Aparência, ambas no Museu de Arte de São Paulo (Masp).

I. O presente ensaio é o resultado de uma investigação de campo realizada no ano 2000, em que foram experimentadas as técnicas educativas dos museus de Filadélfia, especialmente dos museus de arte, e recolhidos todos os materiais pedagógicos então colocados à disposição das escolas e do público em geral. Todo o material recolhido foi elaborado ao longo do mesmo ano e do ano 200 I. Ainda que alguma coisa tenha mudado desde então, a essência e a consistência considerável das atividades educativas dos museus dessa cidade continuam as mesmas e são um interessante ponto de referência para a pedagogia aplicada aos museus.
}

Pro-Posições, Campinas, v. 20, n. 2 (59), p. 225-252, maio/ago. 2009 
são, muitos outros museus americanos. Colocado na entrada da exposição temporária "Pomo Indian Basket Weavers. Their Baskets and the Art M arket", no M useu de Arqueologia e Antropologia da Universidade da Pensilvânia, o pequeno cartaz não só tornava explícita a estratégia adotada pelo museu para a conservação dos objetos, mas dirigia-se, também, à sensibilidade dos visitantes, envolvendo-os nos problemas - nada simples - que 0 museólogo e 0 museógrafo devem enfrentar. Tal cuidado faz com que o visitante se sinta junto com as obras e os organizadores - um dos sujeitos da mostra e predisponha-se positivamente à descoberta de outros mecanismos que regem a exposição. Simples e eficaz, essa atenção faz com que o observador compreenda que tais medidas não são para a proteção da obra contra a sua presença, mas sim a favor da conservação dos objetos, para consentir a sua fruição o mais longamente possível no tempo. Se, por um lado, pede-se compreensão para os limites impostos, por outro, educa-se ao direito à informação sobre as razões de tais limites².

Todavia, não se trata somente do desejo de informar ou de ser transparente. U m pequeno cartaz como este revela, também, a aspiração à comunicação e a vocação pedagógica dos museus de Filadélfia. ${ }^{3} 0$ nde quer que se vá - ao prestigioso Philadelphia M useum of Art, às coleções científicas ou aos vários locais musealizados que evocam a história do nascimento da nação americana - , é surpreendente a riqueza de propostas de interação com os museus oferecidas para todos os níveis de exigência. Sobre este aspecto museológico saliente dos museus da cidade americana concentra-se, portanto, este estudo. $\mathrm{N}$ as linhas que seguem, além de ilustrar as estratégias pedagógicas desses museus, o texto procurará, no caso específico dos museus de arte, evidenciar o enfoque que norteia a comunicação dos conteúdos, através da análise dos itinerários e do lay-out das exposições.

2. No caso específico da exposição de cestos dos índios Pomo, outra surpresa agradável era o vídeo "Roots of Beauty". Apesar de ser projetado sem interrupção, graças a um sistema de células fotoelétricas, o sonoro entrava em ação somente quando o visitante se aproximava e se sentava em um dos bancos colocados à sua disposição. Desta forma, evitava-se o risco de interferência, de poluição sonora no espaço da mostra. A iluminação é um dos aspectos aos quais o Museu de Antropologia e Arqueologia da Universidade da Pensilvânia se demonstra muito sensível. Na ala dedicada às culturas indígenas do sudoeste da América do Norte, por exemplo, cuja incidência de materiais particularmente sensíveis - tecidos, madeira, fibras vegetais - é alta, as vitrinas iluminam-se, automaticamente, somente se os visitantes estão presentes na área. Assim que eles vão embora, as luzes se apagam, para não submeter os objetos a uma exposição inútil aos raios luminosos.

3. Esta vocação se traduz, também, em números importantes: o Philadelphia Museum of Art tem uma "Division of Education" que emprega por volta de 50 pessoas salariadas, metade em período integral e metade em meio-período. Além disso, conta com uma longa relação de colaboradores voluntários, envolvidos em vários níveis de atividade com o público: da informação sobre as propostas didáticas às conferências, das visitas guiadas à distribuição dos impressos na entrada do museu e a monitoragem, em primeira pessoa, das atividades.

Pro-Posições, Campinas, v. 20, n. 2 (59), p.225-252, maio/ago. 2009 
M esmo excluindo alguns institutos que são chamados de "museu", mas que, por não terem um acervo próprio, na realidade não o são - como, por exemplo, o African American M useum -, Filadélfia é uma cidade com uma grande concentração de museus. Convém lembrar que, desde o primeiro povoamento (1682) até a D eclaração de Independência, em 1776, e nos dez anos como capital dos Estados U nidos (1790-1800), a cidade fundada pelo quacre William Penn foi o palco dos principais acontecimentos que levaram ao nascimento da nação americana. No século XVII, aí se estabeleceu Benjamin Franklin, o qual, apesar de ter nascido em Boston, em Filadélfia formou-se, empreendeu as suas múltiplas atividades - editor, jornalista, escritor, estadista e inventor e a ela ligou indissoluvelmente 0 próprio nome. $\mathrm{N}$ ela, foi escrita e atuada a D eclaração de Independência, assim como a Constituição dos Estados Confederais Emancipados, em 1787. Em Filadélfia surgiram o primeiro banco e o primeiro hospital dos Estados U nidos. Todos os testemunhos que sobrevivem desse período - arquitetura, artes aplicadas, objetos de uso comum, etc. e que se concentram na área daquele que atualmente se chama "Independence National H istorical Park" são, desde 1948, objeto de um intenso processo de musealização ${ }^{4}$. M esmo quando a capital já tinha sido transferida para Washington, Filadélfia foi, em 1805, o lugar de criação do primeiro museu e escola de arte do país: a Pennsylvania Academy of the Fine Arts, hoje dividida claramente em escola e museu de arte americana.

Grosso modo, pode-se dizer que os museus da cidade "da amizade fraterna" se concentram em volta do eixo representado pela $M$ arket Street - que atravessa o coração de Filadélfia no sentido leste-oeste; do Delaware River na direção do rio Schuykill -; e ao longo do panorâmico Benjamin Franklin Parkway, o qual, partindo do centro, escorre na direção da colina de Fairmount, a noroeste. $\mathrm{N}$ um certo sentido, eles refletem os momentos de desenvolvimento urbano da cidade: da "Old City", a leste, onde se encontra a maior parte dos testemunhos da história da cidade dos tempos da Independência ou, de qualquer forma, do século XVIII, ao monumental edifício neo-clássico do Philadelphia M useum of Art, erigido nos anos 20 do século passado, na outra extremidade. Entre esses dois pólos, em pleno centro da cidade, entre Broad e Cherry Street, encontra-se o surpreendente prédio em estilo gótico vitoriano da Pennsylvania Academy of the Fine Arts, projetado por Frank Furness e George W. H ewitt, inaugurado em 1876.

4. Toda a área, com seus edifícios históricos e museus, através de um acordo estipulado entre o município de Filadélfia e o Ministério do Interior americano, está sob a tutela do National Park Service, que é um órgão desse mesmo Ministério. Cf. Independence. A guide to Independence National Historical Park. Unite States, National Park Service, Division of Publications, 1982; Handbook I 5. 
Apesar da autonomia administrativa dos diversos institutos, é possível falar de uma verdadeira rede de museus da cidade de Filadélfia 5 . Além da mencionada identificação deles - em função da posição e da arquitetura - com os momentos de desenvolvimento e de afirmação da cultura local, um símbolo da ligação ideal entre os vários museus é o serviço de transporte urbano "PH LASH Visitor Bus", que une os dois pontos extremos da área citada acima. No seu itinerário entre Elfreth's Alley, a rua mais antiga conservada da cidade, e 0 Philadelphia M useum of Art, O "PH LASH" inclui quase todos os museus principais, assim como as igrejas e os monumentos de interesse histórico-artístico. Certamente, trata-se, acima de tudo, de uma ligação de tipo físico, em superfície, que une, antes de mais nada, edifícios, sem por isso refletir obrigatoriamente uma integração mais profunda, um objetivo comum ou uma convergência de métodos de atuação. Porém, no caso específico dos museus de Filadélfia, essa "ligação física" corresponde a um espírito compartilhado e bem enraizado, que se consubstancia num esforço enorme que esses museus - do maior ao menor - fazem para divulgar o próprio acervo; para propor um enfoque das respectivas disciplinas baseado na experimentação (e, portanto, na participação ativa do público); para criar um aparato didático-pedagógico extraordinariamente rico, dirigido a todas as faixas etárias ou categorias sociais.

Ainda que não seja nosso objetivo fazer uma comparação entre a situação de Filadélfia e a italiana, para precisar melhor os termos da nossa exposição, é útil observar que, na Itália, ou pelo menos na Toscana, a didática dos museus ocupa-se fundamentalmente da relação com a escola. Em geral, todos os outros setores da sociedade são excluídos ${ }^{6}$. Ao contrário, nos museus de Filadélfia mas a observação poderia ser estendida também a muitos outros museus americanos, como o Hirshhorn Museum and Sculpture Garden ou o N ational Air and Space M useum, ambos em Washington -, a didática (ou education, como é chamada freqüentemente, no meu parecer, em modo mais apropriado, a didática nos Estados U nidos) vai muito além da relação com a escola. Aliás, a

5. No que diz respeito aos aspectos gerais da gestão dos museus americanos - board of trustees, financiamentos, divisões internas dos papéis e responsabilidades -, veja o amplo relatório de ACIDINI, Cristina - I musei americani. Dietro le quinte di un mito. Torino, Allemandi, 1999.

6. Em ao menos três seminários de pesquisa por mim coordenados na Università Internazionale dell'Arte di Firenze - "I musei civici toscani" (I 992/1993), "Il museo e l'infanzia" (I 995// 996) e "Recenceamento analítico dos museus florentinos" ( 1997// 998) - constata-se que a didática dos museus, na Itália, é dirigida quase exclusivamente à relação com a escola e se traduz maiormente em aulas acadêmicas nas quais o estudante é, sobretudo, um ouvinte passivo ou em conferências para preparar os professores à visita com a escola. Assim, o museu se torna, para os estudantes, um simples prolongamento do programa escolar, o que, infelizmente, não é necessariamente positivo como aproximação às coleções, qualquer que seja a natureza delas. As experimentações como as relatadas por Renate ECO (A scuola col museo. Guida alla didattica artistica. Milano, Bompiani, 1986; "strumenti Bompiani") ainda são raras nos museus italianos.

Pro-Posições, Campinas, v. 20, n. 2 (59), p.225-252, maio/ago. 2009 
escola é somente um dos tantos destinatários dos serviços pedagógicos dos museus de Filadélfia, os quais parecem quase preferir a relação direta com 0 público: visitas auto-guiadas para as famílias, conferências abertas ao público sobre aspectos dos acervos, leituras públicas sobre obras específicas, cursos para todas as categorias sociais e faixas etárias, abundante material didático à disposição dos visitantes e assim por diante. Às vezes, é o próprio lay-out a envolver 0 observador e a motivá-lo à exploração de um tema, de uma coleção ou de um aspecto específico desta. É o caso das period rooms do Philadelphia M useum of Art ou, ainda, do Franklin Court Underground Museum.

Parece-nos, todavia, uma devida homenagem iniciar esta panorâmica com 0 museu estadunidense mais antigo, cujo atual edifício é, também, um dos primeiros construídos para fins museográficos: a Pennsylvania Academy of Fine Arts. O s espaços destinados à exposição permanente, desde a transferência da escola e do acervo, da primeira sede, localizada na C hestnut Street, para a nova sede de Broad Street, encontram-se todos no primeiro andar, onde as clarabóias originais - e, portanto, a luz natural - forneciam a iluminação das galerias, em uma época em que os lampiões de gás ainda não tinham sido substituídos pela luz elétrica.

D esde então até hoje, o andar térreo foi destinado à escola. U m dos aspectos arquitetônicos mais interessantes do prédio é a escada monumental, desenhada inteiramente por Furness, em torno da qual se desenvolve um número considerável de elementos decorativos, que, além de recordar a matriz gótica vitoriana tardia, antecipa, aqui e ali, as formas da Art N ouveau e até 0 geometrismo decorativo do estilo $D$ éco. 0 primeiro andar está dividido em três setores fundamentais: um hall monumental, que olha para a Broad Street, a leste, através de uma grande vidraça gótica, e duas sucessões de salas, que correm paralelas à Cherry Street, no sentido leste-oeste. As duas galerias paralelas estão divididas por um corredor, o qual, no ponto central, abre-se formando uma rotunda, que liga as duas galerias. 0 edifício de Furness e $\mathrm{H}$ ewitt conjuga um decorativismo desenfreado com um admirável senso da funcionalidade e é, em si mesmo, uma obra de arte. Ele se insere com todo o direito na história da arquitetura americana. Entre 1973 e 1976, foi objeto de uma cuidadosa restauração, que livrou as estruturas originais das sobreposições ocorridas durante 0 século passado.

$\mathrm{N}$ o que diz respeito ao lay-out dos espaços expositivos, as fotografias conservadas no arquivo da Academy of the Fine Arts revelam que, desde 1876 até pelo menos 1905, a colocação das obras no espaço, seja na exposição permanente, seja nas mostras dos trabalhos dos alunos, seguia a disposição tradicional dos quadros em várias filas sobrepostas, como nas salas lotadas de obras do Salon parisiense ou nas antigas coleções de pintura. Verossimilmente, a partir 


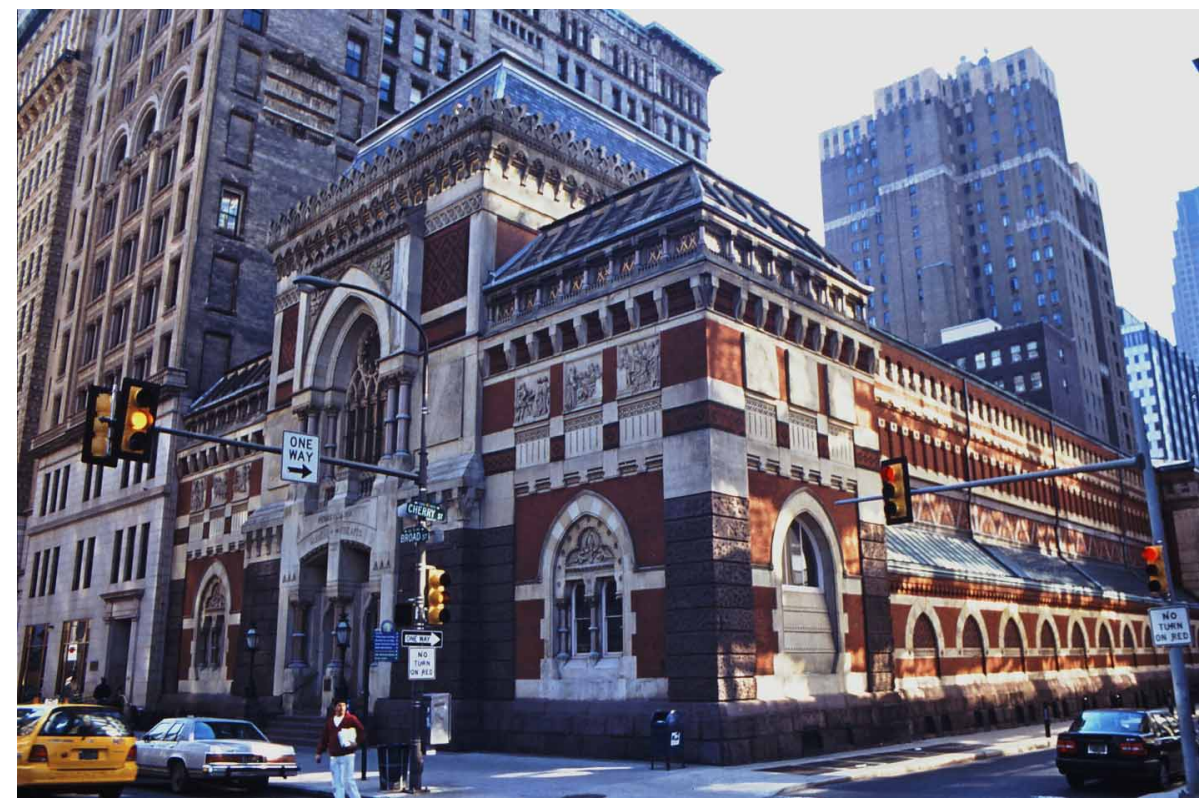

Fig. I: Pennsylvania Academy of the Fine Arts. Edifício projetado pelos arquitetos Frank Furness e George W. Hewitt e inaugurado em 1876.

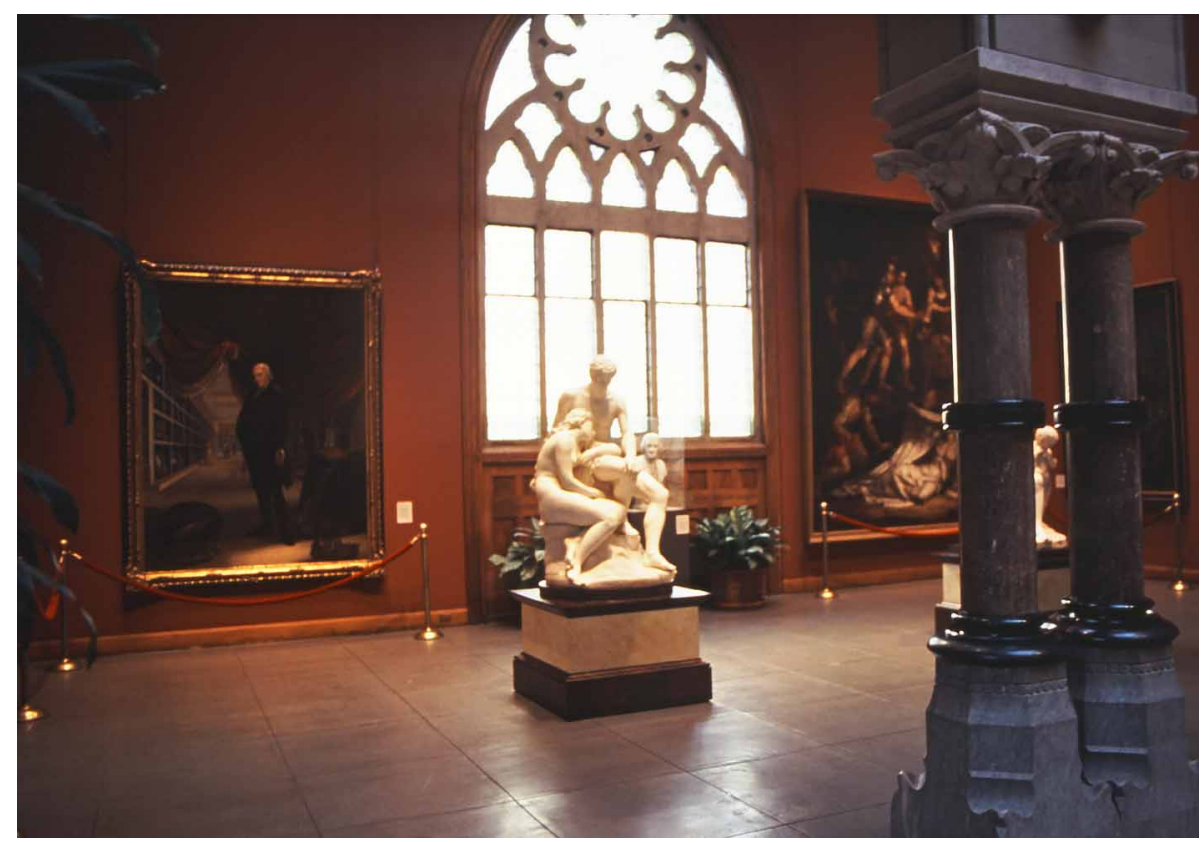

Fig.2: Hall monumental (Washington Foyer) da Pennsylvania Academy of the Fine Arts, onde se vê, à esquerda, o auto-retrato de Charles Wilson Peale "O artista no seu museu". 
dos anos 40, o antigo layout - do tipo "álbum de selos" - deixou o lugar ao alinhamento canônico dos quadros ao longo de um eixo horizontal ideal e uniformador. Essa é a sua disposição atual, embora alguns traços do antigo estilo salon ainda sejam visíveis na parede de fundo da sala dedicada à " $N$ ew Era at the Academy". A ordem das obras propõe um itinerário cronológico e por temas da arte americana, do período colonial até o século XX. Em sintonia com o espírito de transparência, de clareza na relação com o público, cada sala - e, portanto, cada época ou tema - tem uma cor própria, reproduzida também no mapa fornecido na entrada com o guia da galeria, que ajuda o visitante a orientar-se.

Porém, não é no lay-out atual da Academy of the Fine Arts que se encontra o melhor exemplo de realização museológica ou museográfica. Para além do interessante jogo de cores das salas, a colocação das obras é banal e não revela uma sensibilidade especial em relação aos problemas específicos de composição, de espaço e de luz de cada tela - e, por conseguinte, em relação à comunicação destes ao observador. À cuidadosa divisão cronológica e por assuntos do acervo, não corresponde uma atenção específica ao problema da forma. Ao contrário, é no pouco chamativo, mas muito eficaz "Family Resource Center", nos materiais aí predispostos para a relação com o público, que o museu se distingue.

Trata-se de um ponto de pausa predisposto na "Gallery 8", um espaço que não é nada mais que o prolongamento da rotunda na direção da ala norte do edifício e que interrompe, por assim dizer, a sucessão de salas nesse setor da exposição permanente. 0 mobiliário - composto, essencialmente, de duas pequenas mesas redondas com cadeiras e de duas estantes baixas - foi concebido para o uso das crianças, mas a própria denominação desse espaço sugere que a mediação dos adultos é oportuna. As estantes não contêm só publicações sobre o museu e sobre as exposições por ele realizadas, mas também livros de contos e uma grande variedade de fichas (impressas com simplicidade no formato protocolo A4) que convidam as crianças a realizarem pesquisas sobre temas precisos - auto-retrato, paisagem, natureza morta, escultura - ou sobre alguns quadros do museu, como "O tratado entre William Penn e os índios", de Benjamin West. A técnica pedagógica das fichas é a do questionário que leva 0 usuário diante de uma tela e procura chamar a sua atenção para alguns aspectos da pintura. D esde as primeiras frases, a folha dedicada ao auto-retrato para dar um exemplo entre os tantos possíveis - procura envolver o leitor, recorrendo à dimensão mais palpável da vida real: "Você já percebeu a diversidade de expressões que o seu rosto adquire durante 0 dia? Procure imaginar que você acabou de ganhar na loteria ou que foi reprovado num exame. Como seria a sua expressão facial nos dois casos?" Segue uma definição de auto-retrato 
e o convite ao leitor para deter-se diante do quadro "O artista no seu museu", um complexo auto-retrato do pintor Charles Wilson Peale, representante da "G rand M anner Tradition" e, entre outras coisas, um dos fundadores da Academy of the Fine Arts. 0 questionário - com espaços brancos para que 0 "pesquisador" possa anotar suas respostas e suas impressões - continua com perguntas que tendem a revelar, sobretudo, como os objetos incluídos na tela são elementos-chave para a compreensão da personagem, do seu papel social e dos seus interesses ${ }^{7}$. No final, o usuário é estimulado a criar o próprio auto-retrato na parte de trás da folha, onde encontra o desenho de uma moldura já pronto: "Tente fazer seu próprio auto-retrato! O lhe-se no espelho e desenhe 0 artista que vê. Pense nas coisas que gostaria de incluir no desenho para contar às pessoas um pouco mais sobre você e sobre os seus interesses".

Aparentemente, as fichas se dirigem às crianças - que podem realizar sua "pesquisa" e seu desenho com a ajuda dos pais - e aos adolescentes. $\mathrm{N}$ a realidade, conforme uma estratégia difundida nos maiores museus de Filadélfia, esses materiais têm, em geral, a ambição de envolver também os adultos. Ajudando os filhos a fazerem suas descobertas dentro do museu, os pais também entram em contato com informações freqüentemente distantes da própria experiência. $\mathrm{O}$ u, ainda, depois de ter brincado e aprendido algo no museu, os filhos introduzem os novos temas enfrentados em suas conversas com os adultos. D essa forma, os filhos tornam-se um veículo precioso para chegar também aos maiores, menos dispostos, talvez, a aprender noções básicas de história da arte ou técnicas artísticas com outro adulto.

As fichas acima descritas têm, porém, um limite - e, como veremos, isso vale também no caso de alguns materiais pedagógicos do Philadelphia M useum of Art. Embora sejam produzidas no próprio museu de arte, elas ignoram quase totalmente as questões artísticas propriamente ditas: a forma, o estilo, a composição, a cor. Segundo um critério pedagógico muito comum, é preciso envolver a criança, recorrendo, acima de tudo, à sua própria dimensão existencial, a noções que já façam parte da sua experiência ou, de qualquer forma, a dados muito concretos. Assim, a questão do estilo, a exploração da forma, pode parecer abstrata demais, como aproximação à arte, para que a criança se sinta envolvida na atividade de aprendizagem. $\mathrm{N}$ as fichas, a idéia de "função" e de "representação" predomina. São explorados, acima de tudo, os temas figurativos. O s quadros são utilizados como documentos de uma época, da história ou

7. Transcrevo em seguida as outras perguntas: "Look at his facial expression and body position. What is he doing? How can you tell?" "'How does he look? Happy, sad, proud, mad? How can you tell?"/"We can learn a great deal about Mr. Peale and his interests by looking at the clues he has painted in his self-portrait. How can you tell he was an artist?" "'How can you tell he studied dinosaurs?"/"How can you tell he stuffed animals?"/"How can you tell he created a museum?". 
de um grupo social específico. D essa forma, correse o risco de favorecer a percepção da arte como simples "ilustração". O conceito de expressão - já difícil de comunicar a um adulto - não é considerado nem marginalmente. É inegável, entretanto, que as propostas do "Family Resource C enter" da Academy of the Fine Arts estimulam, efetivamente, crianças e adultos à descoberta das obras do museu.

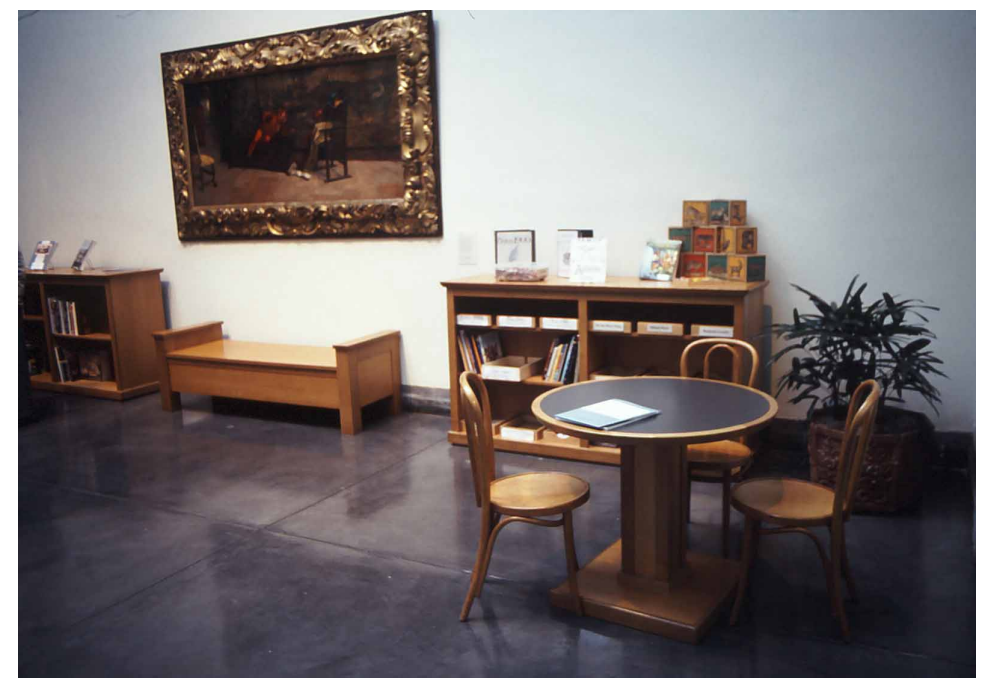

Fig. 3: Family Resource Center da Pennsylvania Academy of the Fine Arts.

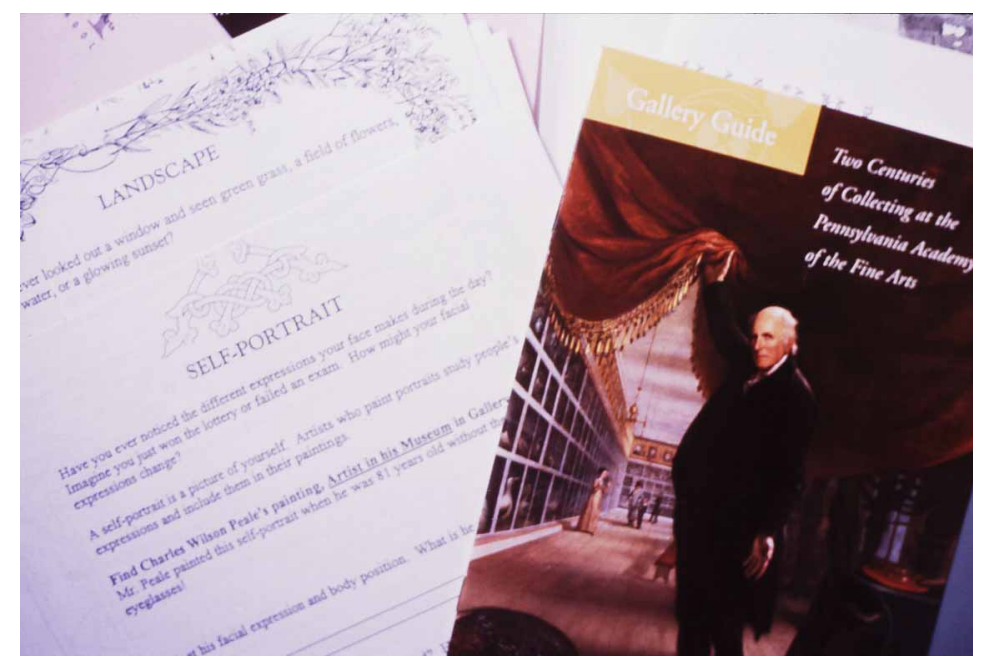

Fig. 4: Fichas pedagógicas propostas pelo Family Resouce Center da Pennsylvania Academy of the Fine Arts. 
Além disso, este é somente um dos aspectos da atividade pedagógica da instituição. C onforme uma tradição entre os museus americanos, o M useum of American Art da Pennsylvania Academy of the Fine Arts, paralelamente à escola, oferece, além dos cursos de longa duração, um calendário repleto de encontros, como os "Saturday Family Programs" e os ciclos de aulas públicas sobre obras de arte intitulados "Art-at-Lunch: Weekly discussions of American Art \& Culture". N estes casos, obviamente, o conteúdo metodológico das oficinas ou das aulas varia conforme 0 docente ou o conferencista envolvido 8 .

Como já foi dito, a Pennsylvania Academy of the Fine Arts ocupa uma posição central na trama urbana de Filadélfia, nas cercanias da City $\mathrm{H}$ all - cuja centralidade administrativa e geográfica é sublinhada pela sua torre altíssima, que compete em altura com os arranha-céus mais modernos e é encimada pela estátua gigantesca de W illiam Penn. Indo na direção leste, a poucos quarteirões do D elaware River, encontramos o Independence $\mathrm{N}$ ational $\mathrm{H}$ istorical Park. Ele compreende um número considerável de edifícios históricos musealizados, a maior parte dos quais foi o palco das assembléias e dos congressos que levaram ao nascimento dos Estados U nidos da América e hospedou os personagens que escreveram a sua história: Benjamin Franklin, Thomas Jefferson, George Washington, John Adams, entre outros. No seu perímetro, está conservado 0 célebre Liberty Bell (o Sino da Liberdade) - verdadeiro símbolo da Independência e objeto de culto dos americanos. 0 Liberty Bell tem um pavilhão inteiro só para si, orientado longitudinalmente no sentido norte-sul e sobre um eixo ideal que aponta para o Independence $\mathrm{H}$ all. N este primeiro exemplo, já está contida a palavra de ordem da museologia e da museografia filadelfiana: comunicar a qualquer custo.

As vidraças amplas da estrutura moderna do Liberty Bell Pavilion ${ }^{9}$ permitem a visão do sino histórico do exterior e, vice-versa, tornam possível, do

8. Por uma questão de método, não é oportuno comentar os ciclos de conferências e aulas públicas, que, nesta exposição, podem ser citados somente como "programação". As minhas pesquisas e "perlustrações" nos museus de Filadélfia concentraram-se no mês de março de 2000. Esses encontros renovam-se continuamente, e não é possível dar um juízo global sobre eles. Todavia, para dar mais um exemplo do empenho da Academy of the Fine Arts em divulgar os conteúdos do museu, entre os inúmeros programas mais ou menos recentes que Cheryl Leibold, curadora do Arquivo da Academy, gentilmente me forneceu, cito o ciclo de conversações ("informal talks") "Viewpoints: Gallery Talks on Works in the Collection", que fazia parte da intensa programação do verão de 1999. Para participar de um dos vinte encontros informais com historiadores da arte ou professores da própria Academy (realizados de 17 de junho a 3 I de agosto), bastava apresentarse, no dia e na hora marcada, no Washington Foyer, em torno da escada monumental de Frank Furness, no primeiro andar. Além disso, é louvável que o museu proponha uma rica série de atividades para explorar o tema de cada exposição temporária por ele realizada.

9. O pavilhão, projetado por Mitchelle Giurgula, foi substituído, recentemente, por um edifício novo, construído na mesma área do parque - porém não mais alinhado com o Indepencence

Pro-Posições, Campinas, v. 20, n. 2 (59), p.225-252, maio/ago. 2009 
interior, a vista do Independence $\mathrm{H}$ all, em cuja torre o Liberty Bell residiu até $1976^{10}$. Embora seja associado, no imaginário popular, com os acontecimentos da revolução, o "sino da liberdade", realizado em Londres em 1751, tinha sido encomendado, na realidade, para a comemoração do 50 aniversário da Carta dos Privilégios da Pensilvânia - uma espécie de constituição democrática da qual William Penn tinha dotado a sua província em 1701. Portanto, no momento em que anunciou a D eclaração de Independência, o sino tinha mais de 20 anos de história, que compreendem, entre outras coisas, uma rachadura ainda antes de ser colocado na torre e duas novas fusões, das quais somente a segunda teve bom êxito. Isso explica a inscrição "Pass and Stow/Philad. a/ M DCCLIII", que se pode ler no sino. 0 nome "Liberty Bell", ademais, não foi adotado pelos revolucionários, mas sim no século XIX, pelos movimentos abolicionistas. A história do Liberty Bell é contada, incansavelmente, por um membro da Guarda Florestal ou por um dos voluntários do National Park Service, que se encontram no local das 9 às 17 horas. $N$ os períodos de fechamento - ou seja, das 17 às 9 horas do dia seguinte -, o serviço de informação é fornecido por uma gravação que entra em função assim que o visitante se aproxima da entrada. No mesmo instante, o Liberty Bell é iluminado automaticamente e torna-se visível, como por magia, através das vidraças, lembrando uma relíquia em uma vitrina.

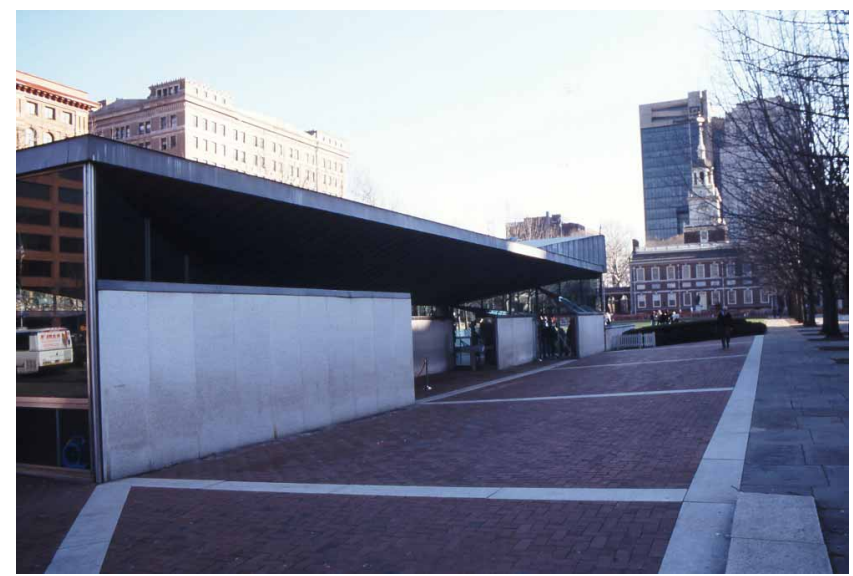

Fig. 5: Liberty Bell Pavilion

Hall - a partir de um projeto de Bohlan Cywinsky Jackson. Entretanto, a ligação visual entre o sino e o Independence Hall foi mantida.

10. Em 1976, ano do bicentenário da Declaração de Independência, o Liberty Bell foi transferido para o Liberty Bell Pavillion, com o objetivo de preservar o edifício histórico do Independence Hall do assédio dos visitantes em aumento constante e, ao mesmo tempo, torná-lo o mais visível e acessível possível aos visitantes do Indepencence Park. 


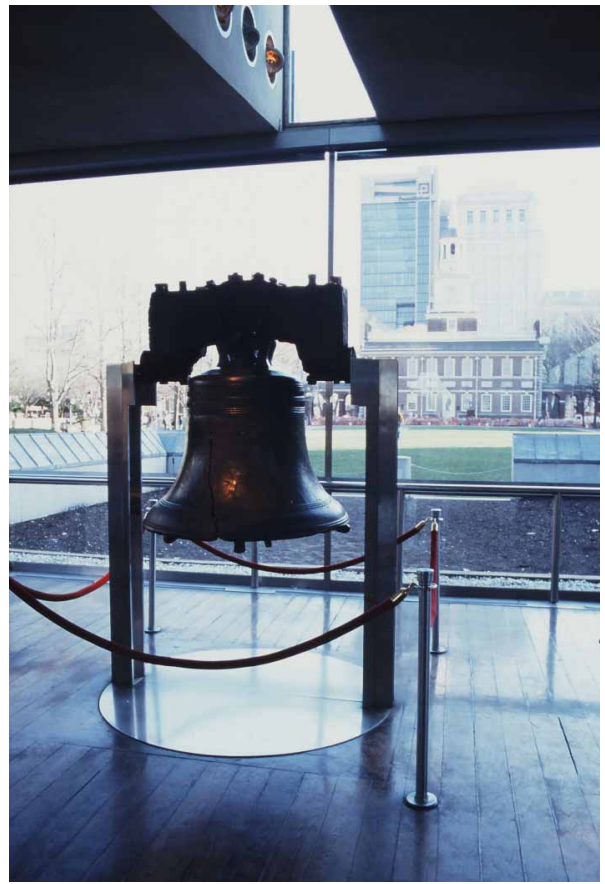

Fig. 6: Liberty Bell e, no fundo, o Independence Hall (antigamente, sede da província colonial da

Pensilvânia e dos Estados Confederais Emancipados).

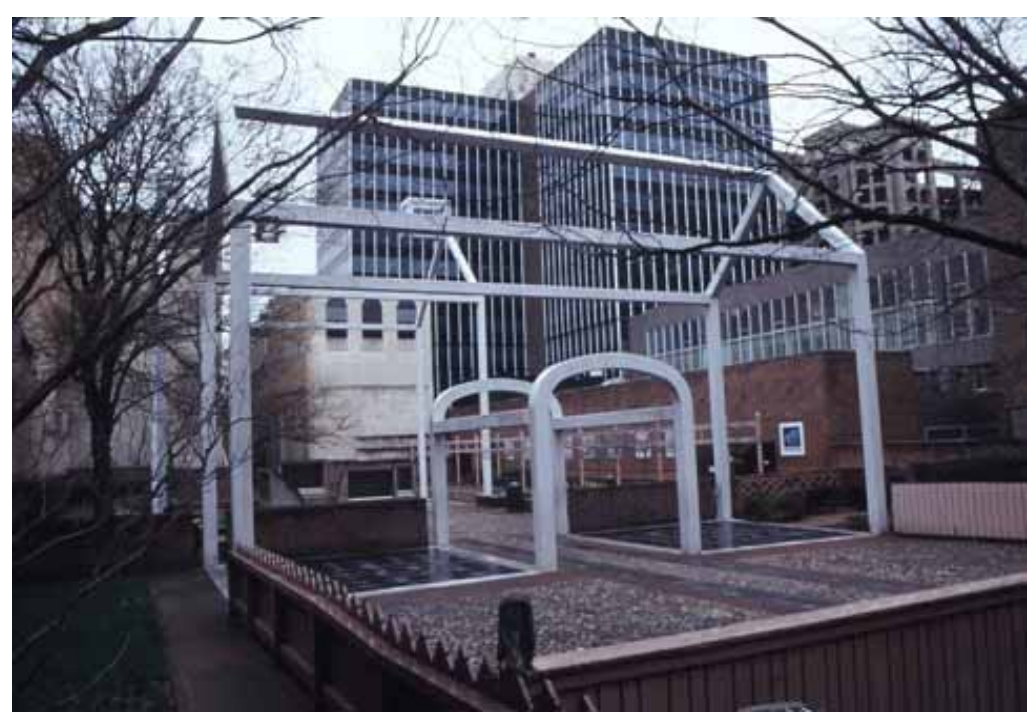

Fig. 7: Franklin Court. Estruturas de aço, que lembram a casa de Benjamin Franklin e a tipografia onde era impresso o seu jornal. 
N ão podemos, aqui, referir-nos a todos os edifícios musealizados e aos museus que se acham no perímetro do Independence $\mathrm{N}$ ational $\mathrm{H}$ istorical Park ou sob a sua administração. Eles ultrapassam abundantemente as duas dezenas ${ }^{11}$. Todavia, não podemos deixar de ilustrar o lugar do Independence Park que reflete melhor o enfoque decididamente pedagógico e experimental dos museus de Filadélfia: o Franklin C ourt U nderground M useum, inteiramente dedicado à figura de Benjamin Franklin. Construída em 1976, a partir de um projeto do arquiteto americano Robert Venturi, trata-se de uma estrutura moderna subterrânea, cujo acesso se encontra no pátio onde, antigamente, ficavam a casa de Franklin e a tipografia que o inventor tinha criado para o genro.

Esses dois edifícios não existem mais, mas são evocados por uma estrutura tridimensional em aço, idealizada pelo próprio Venturi, que repropõe, nas dimensões originais, os seus contornos.

A longa rampa de acesso aos espaços do subsolo - cujas paredes exibem desenhos e textos que lembram o personagem histórico ao qual o museu é dedicado - leva a uma primeira sala longitudinal, na qual, com sobriedade, estão dispostos originais e réplicas de objetos que lhe pertenceram e algumas das suas invenções. Entre outros, podem-se admirar a "Armonica" - instrumento musical criado por Franklin em $1762^{12}$-, uma poltrona que se transforma em escada para biblioteca e uma réplica da estante musical com quatro lados para quartetos (a original está na Historical Society of Pennsylvania) estas últimas também inventadas por Benjamin Franklin.

A sala seguinte reserva a surpresa quase brutal da passagem ao mundo contemporâneo dos cartazes publicitários luminosos das metrópoles americanas. D e fato, nela não há objetos, mas escritas em neon colorido que se acendem e apagam continuamente, alternando-se, para lembrar-nos os vários atributos de

II. Entre outros, citamos o já mencionado Independence Hall, construído entre 1732 e 1756, importante exemplo de arquitetura georgiana; o Segundo Banco dos Estados Unidos com a sua galeria de retratos; o Carpenters' Hall; a City Tavern (reconstruída), onde se oferece a experiência de uma refeição colonial; o pequeno museu arqueológico de Market Street, n. ${ }^{\circ} 3$ I , com os achados das escavações da Franklin Court; a tipografia do século XVIII, recomposta em uma das casas que tinham pertencido a Benjamin Franklin, na Market Street; a Declaration House, onde Thomas Jefferson escreveu a Declaração de Independência. Em cada um desses lugares - assim como em todos os outros não citados -, é oferecida uma narração do seu significado histórico ou uma demonstração prática - como, por exemplo, a técnica de impressão na época de Franklin (Franklin Court Printing Office).

12. O instrumento é composto por 37 tigelas de vidro que rodam dentro de um recipiente cheio de água. Quando as bordas molhadas dos vidros são tocadas com os dedos, a fricção provocada pelo movimento de rotação produz sons suaves, aveludados. A armônica tem quase três oitavas e despertou o interesse de Mozart e Beethoven, que escreveram peças para ela. Um CD de músicas executadas na armônica está à venda nas lojas ou nas livrarias da Eastern National no perímetro do Independence Park.

Pro-Posições, Campinas, v. 20, n. 2 (59), p. 225-252, maio/ago. 2009 
Benjamin Franklin: cidadão, estadista, tipógrafo, editor, inventor, cientista, escritor, diplomata. As paredes da sala são inteiramente revestidas com espeIhos, o que amplifica o efeito "Times Square". 0 contraste com a primeira sala é realmente grande - e igualmente eficaz em ajudar o visitante a entrar no mundo de Benjamin Franklin, que do estro e da inventividade tinha feito um verdadeiro mote existencial. A técnica - e a tecnologia - normalmente utilizada na publicidade é aqui transformada num válido instrumento pedagógico. Esta sala é, também, a passagem obrigatória para outro setor do museu, no qual a interatividade domina. Assim que entra no novo ambiente, o visitante depara-se com aproximadamente 50 aparelhos telefônicos sustentados por estacas de cerca de um metro de altura, distribuídos em uma superfície de ao menos 40 metros quadrados. $\mathrm{N}$ o fundo da sala, um grande painel luminoso fornece uma lista de nomes de escritores, intelectuais, cientistas, estadistas, etc. que, nos Estados U nidos e no mundo, relacionaram-se com ou exprimiram uma opinião sobre Benjamin Franklin. Como em uma lista telefônica, cada nome é seguido de um número. Para conhecer a opinião que um determinado personagem tinha sobre Franklin, o visitante deve utilizar um dos telefones.

Fica claro que, quando é possível, não se incita o visitante somente a olhar al go, mas procura-se envolvêlo em uma experiência. Este éo princípio educativo que rege a museologia em Filadélfia. Para prestar, ainda, uma homenagem a Benjamin Franklin, poderíamos dizer, adaptando ao nosso discurso museológico a máxima "Well done is better than well said", contida no seu Poor Richard's Almanack, que "viver em primeira pessoa é melhor do que viver por intermédio do que os outros contam".

Esta máxima é seguida ao pé da letra por outra interessante experimentação museográfica de Filadélfia: o Please Touch M useum (M useu Por Favor Toque!). I naugurado em 1976, foi concebido para as crianças menores. Criado em franco contraste com o museu tradicional, onde vige a lei do hands off! (literalmente, não toque!), ele é um museu, como o próprio nome dá a entender, onde se pode pôr a mão em tudo. Não se trata de um acervo de objetos, de obras de arte, de esculturas, mas sim de uma seqüência de ambientes onde a criança pode experimentar vários aspectos da vida que, normalmente, são do domínio adulto. No seu percurso, no conjunto das instalações permanentes, encontram-se, por exemplo, um supermercado e um estúdio de televisão realizados sob medida para os pequenos: todos os objetos e os mecanismos foram reduzidos à escala infantil ${ }^{13}$.

13. Situado, até há pouco tempo, nas cercanias do Franklin Institute Science Museum, o Please Touch Museum foi transferido para o Memorial Hall, edifício de que falaremos mais adiante e que está ligado à origem do Phildaelphia Museum of Art. A transferência coincidiu, também, com a expansão do museu, que, conforme as previsões, acrescentou às seções já existentes uma redação de jornal, um centro médico e outros projetos. 


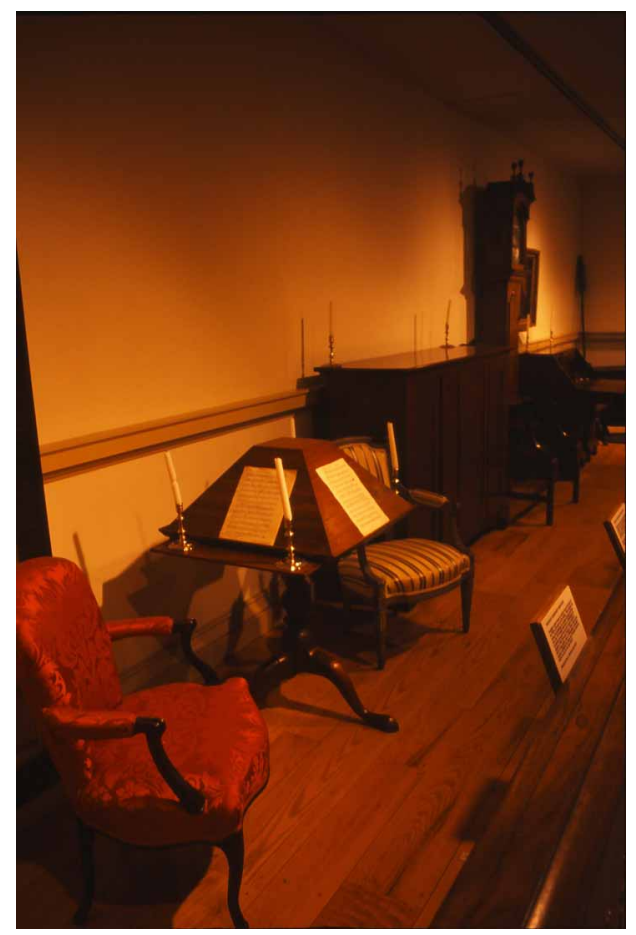

Fig. 8: Sala do Franklin Court Underground Museum com os objetos de Benjamin Franklin, entre os quais se vê a réplica da estante para quartetos

Fig. 9: Sala interativa do Franklin Court Underground Museum.

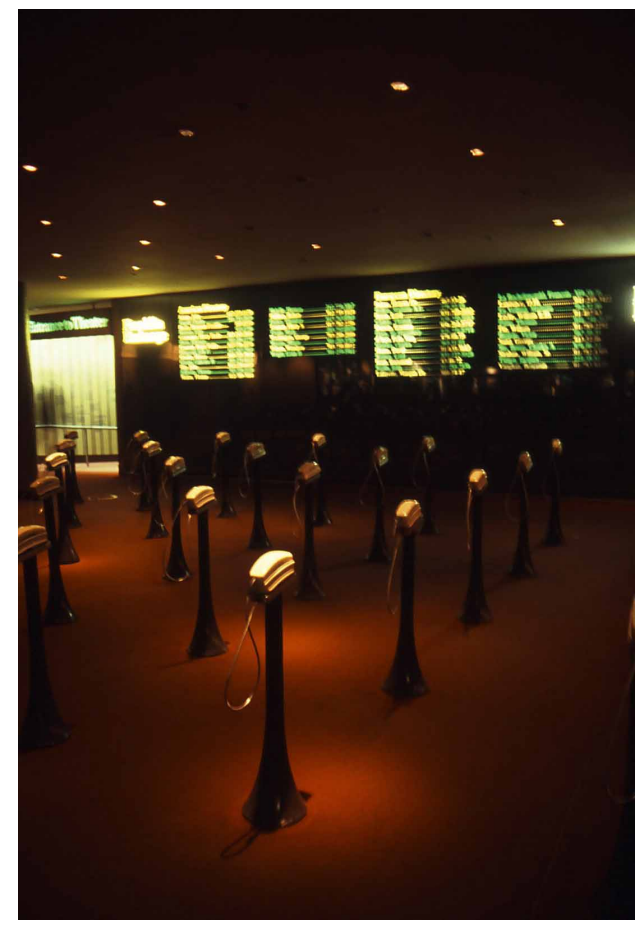


N a seção dedicada à "Ciência do Supermercado", tudo - carrinhos, prateleiras, caixa com sistema de leitura ótica do código de barra - tem o tamanho adequado para as crianças, que podem "fazer a compra" em primeira pessoa ${ }^{14}$ ou "trabalhar como caixa", sem ter que superar continuamente os obstáculos físicos que o mundo real, concebido para o tamanho adulto, Ihes impõe sistematicamente. 0 mesmo acontece no estúdio de televisão, equipado com uma telecâmera fixa verdadeira, uma mesa de controle e outros aparelhos, um painel de fundo cenográfico com a fotografia panorâmica da cidade para o noticiário e outro para a previsão do tempo e um camarim com roupas e o necessário para a maquilagem ${ }^{15}$.

No ano 2000, na área dedicada às instalações temporárias, uma seqüência de ambientes inspirados em Alice no país das maravilhas dava às crianças a possibilidade de vivenciar as surpresas e o estranhamento típicos do conto de Lewis Carrol.

$\mathrm{N}$ ão se trata, porém, de deixar a criança totalmente livre e utilizar as instalações do Please Touch M useum como um simples play-ground. Para evitar qualquer mal-entendido, em um cartaz bem visível, na entrada, com a proposta do museu, recomenda-se a presença dos adultos. $E$ assim é também na introdução dos folders fornecidos. "We're designed so that adults and children can learn and explore together. The role of the museum is to ensure that the activities are educational, fun and safe" é 0 que se pode ler no folder intitulado "Please Touch M useum, The Children's M useum of Philadelphia" - no qual se acham, também, as informações gerais, uma panorâmica das diversas seções e 0 mapa do museu.

A concepção do Please Touch M useum é, com certeza, insólita em relação aos museus tradicionais. Ele não tem um acervo, mas uma série de ambientes predispostos para a experiência. $\mathrm{N}$ ão deve, portanto, enfrentar os problemas complexos de conservação e salvaguarda dos objetos. Poderíamos perguntarnos se a sua definição como museu não é, de certa forma, indevida e se pode criar mal-entendidos - como, por exemplo, a idéia de que a preservação de uma coleção de arte ou de objetos preciosos e, portanto, a proibição de tocá-los limitem a experiência. D a minha parte, acho que o Please TouchM useum serve como uma advertência saudável: ou seja, que, de uma forma ou de outra, a

\footnotetext{
14. Em São Paulo, assim como em outras capitais do mundo, muitos supermercados e grandes lojas põem carrinhos e cestas à disposição também das crianças que vão fazer as compras com os pais. Receio, porém, que, neste caso, mais do que uma saudável iniciativa pedagógica, seja uma astúcia para forçar as famílias ao consumo. A criança se diverte, enchendo o seu carrinho; os pais pagam!

15. $O$ estúdio de televisão do Please Touch Museum é patrocinado pela rede de televisão NBC Canal 10.
} 
experiência deve ser provocada; que todos nos achamos na condição de criança quando nos deparamos com algo que não conhecemos; e que a maneira melhor de aprender a conhecê-lo é vivenciá-lo. Em maior ou menor grau, todos os museus de Filadélfia parecem ter aceitado esse desafio. D esde as estruturas analisadas acima até o Franklin Institute Science M useum e a Academy of $\mathrm{N}$ atural Sciences, ninguém economiza forças e empenho para favorecer a experiência.

Em um contexto tão favorável à pesquisa pedagógica, não surpreende que 0 príncipe dos museus de Filadélfia, o Phildael phia M useum of Art, tenha uma das maiores di visions of education de toda a América, senão a maior. Para dar conta da vastidão das suas coleções e do seu espaço, o museu precisa de uma grande concentração de esforços: desde a intervenção dos especialistas de cada disciplina, assim como de questões pedagógicas, até o pessoal que executa concretamente os programas educativos, as visitas guiadas, a redação das fichas e dos cartazes, a monitoração das atividades com o público, o serviço de informação, etc.

Porém, antes de ilustrar os vários tipos de atuação didática do Phildelphia M useum of Art, convém retraçar, ainda que brevemente, a sua história e descrever a natureza das suas coleções ${ }^{16}$. 0 museu nasceu quase como uma conseqüência da Exposição Internacional de Filadélfia de 1876, a primeira realizada nos Estados U nidos. Para a ocasião - que coincidia com o primeiro centenário da Independência americana - , tinha sido erigido, no Fairmount Park, um grande edifício destinado à exposição das artes e dos produtos industriais do mundo. $\mathrm{O} \mathrm{M}$ emorial $\mathrm{H}$ all, como é conhecido hoje em dia, tinha sido concebido - seguindo o modelo do Grand Palais parisiense - como uma estrutura permanente, destinada a viver mesmo depois do encerramento da grande mostra. A afluência enorme de público e 0 interesse demonstrado levaram os administradores locais a fundar o Pennsylvania M useum and School of Industrial Art, como era denominado nos seus primeiros anos. Como sede do novo museu foi escolhido, exatamente, o $\mathrm{M}$ emorial $\mathrm{H}$ all.

Com o tempo e graças a uma campanha de aquisições das mais férvidas durante a qual as doações, como no processo de formação e desenvolvimento da maior parte dos museus americanos, tiveram um papel fundamental -, 0 espaço do $\mathrm{M}$ emorial $\mathrm{H}$ all revelou-se insuficiente e inadequado para a satisfação das várias funções que devia desempenhar. De 1919 a 1928, empreendeu-se a construção do imponente, cenográfico edifício neoclássico, que lembra, pelo menos na forma da fachada principal, o célebre altar de Pérgamo e a sua escadaria monumental (atualmente, reconstituído na Ilha dos M useus, em Berlim) ${ }^{17}$.

16. No que diz respeito à história do edifício e da formação do acervo, ver, também, Philadelphia Museum of Art. Handbook of the Collections. Philadelphia Museum of Art, 1995. 
0 "templo" filadelfiano é o resultado da intervenção de vários arquitetos. Apesar disso, como observa Anne d'H arnoncourt ${ }^{18}$, não deixa transparecer nenhuma indecisão formal, apresenta uma grande unidade de estilo.

D urante a construção da nova sede, o museu, então dirigido pelo arrojado historiador da arquitetura Fiske Kimball, fez algumas das suas aquisições mais importantes, que acabariam constituindo, mais tarde, as famosas period rooms. $\mathrm{N} \mathrm{a}$ onda do que se estava fazendo em Berlim - ou seja, a transferência, principalmente em campo arqueológico, de inteiras estruturas arquitetônicas ${ }^{19}-$, 0 Philadelphia M useum of Art enviou emissários mundo afora "à procura de interiores arquitetônicos bem conservados e à altura das grandes obras de arte que eles, segundo os planos de Kimball, teriam hospedado"20. Assim, somente em 1928, chegaram ao museu o portal românico da igreja da Abadia de SaintLaurent de Cosne-Cours-sur Loire (França central); o interior de uma casa holandesa de H aarlem do século XVII; o "Grand Salon" do século XVIII do C astelo di D raveil (França); um verdadeiro "pavilhão do chá" japonês, construído por volta de 1917 pelo arquiteto 0 gi Rodo (1863-1941) com elementos de uma casa de chá do século XVIII; e, enfim, o claustro românico resultante da reunião de elementos provenientes da Abadia de Saint-G enis-de- Fontaines (Roussillon, França meridional), outros elementos originários do sudoeste da França e uma fonte do século XII do M osteiro de Saint-M ichel-de-Cuxa (Pireneus orientais), complementados pelas integrações de uma restauração.

Q uando chegaram ao museu, essas estruturas arquitetônicas encontraram amplos espaços idôneos para acolhêlas, flexíveis seja nas dimensões, seja nas possibilidades para criar itinerários coerentes. É por isso que hoje encontramos, nos vários percursos do Philadelphia M useum of Art - os quais, de qualquer forma, baseiam-se na tradicional divisão cronológica e por áreas culturais -, as period rooms, onde o público pode ter uma sensação mais forte da história, mais elementos sobre culturas que originaram a maior parte das obras recolhidas no museu, de franca tendência universalista. Além disso, as period rooms são um precursor importante dos cloi sters de $\mathrm{N}$ ova I orque, reconstituídos entre

17. Entre 1878 e 1886, as escavações arqueológicas conduzidas por Carl Hermann em Pérgamo trouxeram à luz uma quantidade considerável de fragmentos - sobretudo, relevos em mármore - do altar dedicado a Zeus e Atena. Transportados para Berlim, os fragmentos serviram de ponto de partida para a reconstrução do inteiro altar do século II a. C. em um museu especialmente criado para contê-lo, junto com outras estruturas arquitetônicas monumentais antigas. $\bigcirc$ Pergamonmuseum foi projetado por Alfred Messel e Ludwig Hoffmann, entre 1909 e 1930.

18. "Introdução" do Philadelphia Museum of Art. Handbook of the Collections; p. II .

19. Já falamos sobre o altar de Pérgamo. Outras duas transferências espetaculares para Berlim foram as das portas de Ishtar (século VII A.C.), que tornaram possível a reconstrução da rua das procissões de Babilônia, e a fachada da entrada do mercado de Mileto (século II D.C.).

20. Anne d'HARNONCOURT, op. cit., p.I5. 
1934 e 1938, a partir de uma grande quantidade de fragmentos também transportados, principalmente, como no caso do portal e do claustro românicos de Filadélfia, da França central e meridional ${ }^{21}$.

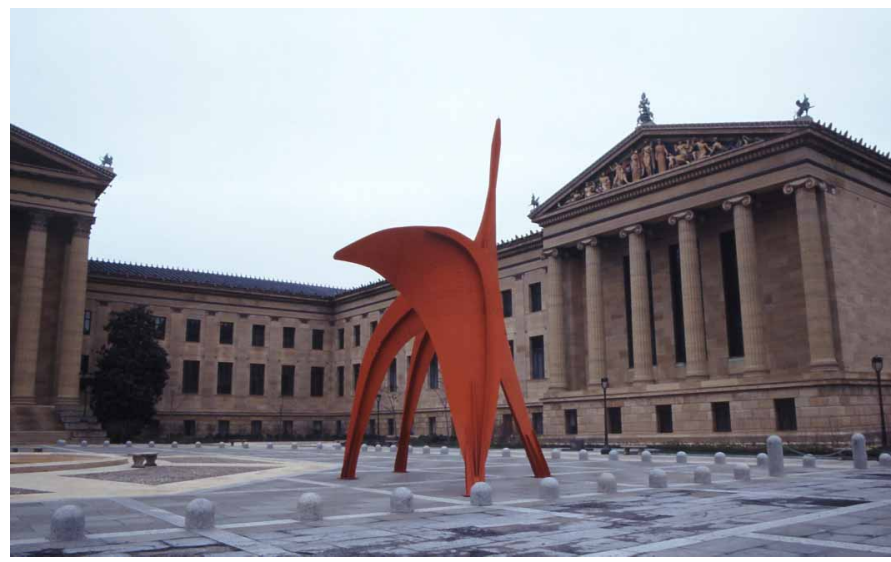

Fig. I I : Philadelphia Museum of Art. Ala direita do edifício visto da praça à extremidade do Benjamin Franklin Parkway.

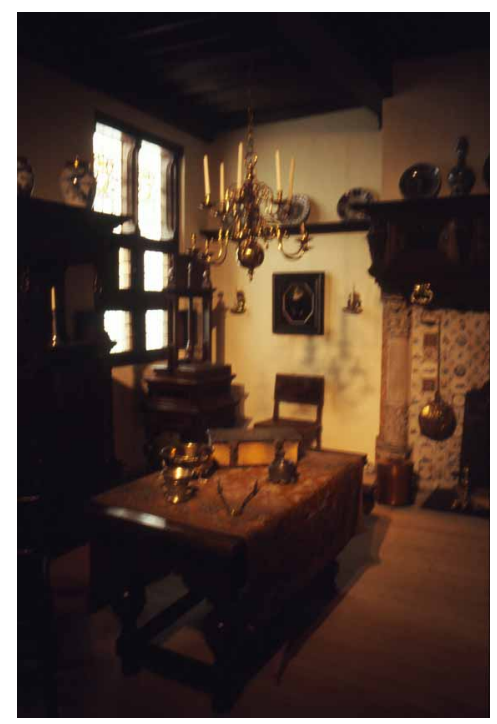

Fig. 12: Interior holandês do século XVII (de uma casa inserida no edifício de uma fábrica de cerveja de Haarlem, conhecida como "Het Scheepje", ou seja, "Navio Pequeno").

21. O claustro românico do Philadelphia Museum of Art partilha a sua origem com a da fonte de um dos claustros novaiorquinos, que, vice-versa, é onde se encontrava a fonte pertencente ao museu da cidade da Independência. 
Ainda na onda da contextualização histórico-ambiental - da qual, no início do século XX, um dos pioneiros, na Europa, tinha sido Wilhelm von Bode, diretor dos museus de Berlim -, muitos fragmentos arquitetônicos foram absorvidos na própria estrutura interna do novo edifício, de modo que não é raro encontrar, especialmente nas salas de arte européia dedicadas aos anos 1100 a 1500, arquitraves, arquivoltas, lunettes ${ }^{22}$, capitéis, janelas, intradorsos, molduras, que desempenham suas funções originárias nas salas onde estão quadros que remontam ao mesmo período. Além disso, algumas salas apresentam junto com os quadros - móveis, tapeçarias e outros objetos de época. Sem a ambição de configurar-se como verdadeiras period rooms - as quais requerem certa inteireza para provocar a sensação de "viagem" no tempo e no espaço -, tais salas pretendem, de qualquer forma, fornecer, ainda que através de simples traços, uma idéia de "contexto" ambiental23.

Assim, Kimball, que dirigiu o museu por quase 30 anos, a partir de 1925, deixou a sua marca indelével, seja na diversidade dos materiais recolhidos, seja no modo de apresentá-los ao público. 0 utro aspecto significativo do Phildelphia M useum of Art é a sua coleção extraordinariamente rica de objetos das assim chamadas artes aplicadas, dos tecidos às armas e armaduras; das pratas aos móveis, às tapeçarias e às cerâmicas. Adquiridos, em grande parte, através de doações, esses objetos refletem os primórdios do museu - a Exposição Internacional de 1876, que, baseando-se no modelo do então South Kensington M useum de Londres (atualmente, Victoria and Albert M useum), tinha revelado ao público de Filadélfia todo o fascínio das artes aplicadas provenientes de todas as partes do mundo. Muitas das primeiras aquisições do museu foram de objetos expostos na grande feira.

Excluindo-se o âmbito arqueológico - deixado inteiramente aos cuidados do University of Pennsylvania's M useum of Archaeology and Anthropology -, é difícil individuar um momento histórico ou uma área geográfica que não se ofereça ao público através de um objeto, de uma tela, de uma escultura ou de um fragmento arquitetônico do Philadelphia M useum of Art. Limitando-nos a examinar somente a pintura, constatamos que 0 acervo começa a partir do século XIV em Siena (I tália), para chegar até os contemporâneos Anselm Kiefer e Chuck Close. Alguns momentos ou escolas estão representados por obras de altíssima qualidade, como o díptico de Rogier van der Weyden com Cristo

22. Palavra italiana que indica a porção de parede constituída pela intersecção de uma abóbada com a própria parede; freqüentemente, na arquitetura antiga, preenchida com pinturas, mosaicos ou relevos, os quais, sendo fechados por um arco na parte superior, também são chamados lunette. Pode ser o espaço ou a decoração com a mesma forma sobre uma porta ou uma janela.

23. Por exemplo, as salas 208, 209, 250 e 252. 
crucificado e o lamento de M aria e João Batista ou o minuto painel atribuído a Jan van Eyck, com Os estigmas de São Francisco, no que diz respeito à pintura do século XV em Flandres. Já não podemos dizer o mesmo em relação ao século XV italiano, do qual o museu possui apenas, como obra verdadeiramente significativa, um dos painéis pintados em ambos os lados do Políptico da $\mathrm{N}$ eve - fruto da colaboração de M asolino e M asaccio - , o qual representa, sim, a aquisição de consistência, plasticidade, volume na concepção da figura humana, mas que ainda não oferece as características de espacialidade racional que distinguem, inicialmente, o século XV em Florença; depois, na Itália; e, sucessivamente, na Europa. Já a coleção de impressionistas, pós-impressionistas e das várias correntes das vanguardas históricas do século XX é muito farta, ainda que estejam quase completamente ausentes os expressionistas alemães. Estes poucos exemplos são suficientes para dar uma idéia da complexidade do acervo e, portanto, da multiplicidade de problemas que o museu tem que enfrentar para comunicar seus conteúdos ao público.

Voltando à questão pedagógica que, como já foi dito, ocupa uma posição central nas atividades do Philadelphia Museum of Art, podemos dizer que as period rooms - com a capacidade que têm de evocar ou "transportar" o visitante para outros tempos e continentes - já são, por si sós, um deflagrador extraordinário de experiência ${ }^{24}$. 0 contato direto com as estruturas arquitetônicas, seus revestimentos, suas decorações e seu mobiliário é infinitamente mais evocativo do que qualquer descrição ou do que a visão de objetos isolados. Ademais, passar de um autêntico interior holandês do século XVII a um salão rococó francês do século XVIII; de um claustro românico ao escritório de um erudito chinês do final dos Setecentos; ou, ainda, de um living room inglês ao hall de recepção do palácio de um nobre chinês dos Seiscentos obriga ao confronto entre os vários estilos e à tomada de consciência, através da experiência direta e da comparação, das características específicas de cada época ou área geográfica ou, pelo menos, de alguns de seus traços culturais. Ao contrário, as salas que, sem a originária inteireza das period rooms, misturam artes aplicadas, móveis, esculturas e pinturas acabam rebaixando-se ao nível de simples decoração, sem dirigir uma atenção específica às qualidades intrínsecas de cada obra.

Uma das muitas funções desempenhadas pela "D ivision of Education" do

24. Em sintonia com o critério de transparência na comunicação com o público, que mencionamos na introdução, nessas reconstituições indicam-se sempre as integrações devidas a restaurações ou, como no caso do interior holandês, os objetos que, apesar de serem originais e pertencerem à mesma época e área cultural, não se encontravam originariamente no ambiente reconstituído no museu, mas que vêm preencher o vazio dos originais perdidos. Este critério está para a recomposição de ambientes assim como as integrações com o "traçado" ou com a "abstração cromática" estão para a restauração de afrescos. 
Philadelphia M useum of $\mathrm{Art}^{25}$ é a de colaborar na preparação das etiquetas das obras e dos textos didáticos disponíveis nas salas - sejam eles fixados nas paredes ou nos móveis, em forma de fichas plastificadas colocadas à disposição dos visitantes. É freqüente, nos manuais de museologia e museografia, encontrar uma análise sobre a forma das etiquetas e dos suportes para a informação do público, mas é raro que se discuta o conteúdo da informação. $\mathrm{N}$ as linhas que seguem, comentaremos principalmente os conteúdos.

No que se refere ao museu de Filadélfia, é preciso dizer, desde já, que a quantidade de informação colocada à disposição do visitante - e não fazemos, aqui, a distinção entre público jovem e adulto - é considerável. Especialmente elaborado é o sistema das fichas plastificadas - as cards - que o visitante pode pegar da estante e conservar durante a visita à sala à qual a ficha se refere ${ }^{26}$. Elas

25. Seria impossível, neste relato, enfrentar todos os aspectos da atividade didática do Philadelphia Museum of Art. Entretanto, na documentação que Danielle Rice, diretora da "Division of Education", me forneceu gentilmente, - da qual fazem parte, também, alguns impressos de uso interno do seu Departamento -, pude contar nada menos do que 21 categorias diferentes de iniciativas pedagógicas, que aqui enumero: I. "A is for Art" (CD-R interativo com atividades baseadas em 33 obras do museu); 2. "Project ArtLine and Distance Learning Projects" (utilização das linhas telefônicas digitais ISDN para videoconferências, que ligam o museu com escolas de localidades remotas ou de outros estados americanos, com a possibilidade de interação em tempo real entre os educadores do museu e os estudantes); 3. "Experiment with Virtual Tours" (realização de um protótipo de visita virtual ao museu, destinado ao público das bibliotecas, dos aeroportos, das estações ferroviárias, etc.); 4. "Gallery Lessons for School Children"; 5. "Gallery Lessons for Preschool Children"; 6. "Summer Tours"; 7. "In-Service Training for Teachers"; 8. "Children's Art Classes"; 9. "Family Programs"; 10. "Outreach Programs" (atividades realizadas fora do museu, dirigidas a categorias impossibilitadas, em geral, de visitar o museu - idosos e deficientes físicos em hospitais ou asilos, detentos em prisões de low-security, entre outras); I I . "College Programs"; 12. "Programs for Audiences with Special Needs" (laboratórios mensais para idosos, pessoas con incapacidades mentais ou de desenvolvimento, doentes de Aids); 13. "Form in Art" (aulas em ateliê ou nas salas do museu para cegos ou pessoas com problemas de vista); 14. "Art History Courses and Workshops"; I 1. "Gallery Lectures (Spotlight Talks)"; 16. "Tours for Adults Visitors"; 17. "'Foreign Language Tours"; I 8. "Guest Lectures and Symposia"; 19. "Concerts" (o programa dos concertos são concebidos para estabelecer relações temáticas ou históricas com as exposições temporárias em andamento no museu ou com aspectos do acervo); 20. "Performances" (dança, poesia, teatro, artes performáticas); 21 . "Films" (entre outros, filmes sobre arte e artistas e filmes cujos temas tenham uma relação com aspectos do acervo ou com as exposições temporárias em andamento).

26. As cards, um veículo de informação que não é exatamente uma novidade, são utilizadas, também, por outros museus americanos, como, por exemplo, a National Gallery of Washington. Os museus franceses também fazem uso desse tipo de fichas, que se encontram, entre outros, no Musée National d'Art Moderne et Contemporaine do Centre Georges Pompidou, em Paris. Alguns anos atrás, o Museu de Arte de São Paulo também as utilizou, colocando-as em recipientes predispostos nos próprios bancos de madeira no centro das salas. Nestes casos, porém, as fichas são utilizadas simplesmente para comunicar noções prontas sobre as obras ou o período histórico, e não para propor alguma atividade.

Pro-Posições, Campinas, v. 20, n. 2 (59), p.225-252, maio/ago. 2009 
são divididas em duas categorias: as cards informativas sobre uma ou mais obras contidas na sala, caracterizadas pela cor vermelha, e as activity cards, amarelas, que propõem, através da técnica da "caça ao tesouro", a exploração de um aspecto do acervo ou de um tema presente em várias obras do museu. Um bom exemplo da primei ra categoria é o da ficha sobre os "I talian Altarpieces" (retábulos italianos) na sala dedicada à "Early Italian Painting" (Gallery 210). A sala contém certa quantidade de partes de trípticos ou polípticos - entre as quais se encontram um pináculo da M aestà, de Duccio, para a Catedral de Siena; 0 painel central com a M adona com a criança, de um políptico de Pietro Lorenzetti; e uma predella pintada por Taddeo di Bartolo. A ficha informativa explica, numa linguagem clara e acessível às várias faixas etárias e categorias de público, o conceito de "políptico" e descreve a sua estrutura tradicional - painel central, painéis laterais, predella, primeiro e segundo renque (tier), pináculos, cúspide, etc. - , a fim de que o observador possa enfocar melhor as obras ou fragmentos que vê. D essa forma, não só se expõe uma obra, mas tenta-se oferecer ao público, levando em consideração a sua condição de outsider, os instrumentos para a compreensão e para a experiência ${ }^{27}$.

N a mesma sala, uma ficha com o título "Gold" (ouro), desta vez caracterizada pela cor amarela - a das activity cards - , explica a técnica da douradura, do uso do fondo oro, do ouro nas auréolas, na decoração das vestes e nas molduras. Em seguida, exorta o visitante (jovem ou adulto), fornecendo-Ihe indícios, a achar, no museu, outras pinturas nas quais é usado o ouro. 0 utro exemplo interessante de card encontra-se na sala 206, dedicada ao extraordinário díptico de Rogier van der Weyden citado anteriormente. A ficha refere-se às várias hipóteses sobre a função do díptico - peça para um altar, painéis de um políptico, portas de um armário ou de um órgão - e contém, também, fotografias de alguns polípticos, entre os quais, um particularmente elaborado da escola flamenga do século XVI, originário de Antuérpia, que se acha na sala 225 do museu. 0 visitante desejoso de empreender uma "viagem" em torno do tema "políptico" pode dirigir-se àquela sala, onde, além da surpreendente obra realizada por anônimos, encontra outra card, a qual reproduz o políptico aberto e fechado. $\mathrm{N}$ a sua colocação atual, a obra reencontrou o iconóstase de mármore e alabastro, de clara ascendência renascentista italiana, da capela do

27. No seu interessante artigo "The art idea in the museum setting", Danielle Rice aponta a incapacidade dos "profissionais da arte, os especialistas" de partilhar a sua experiência com o público não iniciado (os outsiders): "it is difficult for them to remember that outsiders cannot value the same things that they do". A comunicação no museu só pode ser eficaz se procurar conhecer o próprio público e for ao encontro das necessidades dele, se os insiders não se dirigirem somente a outros insiders, mas encontrarem uma linguagem acessível, que envolva também os outsiders na experiência da arte. The Journal of Aesthetic Education, v. 25, n. 4, pp. 127-136, Winter 1991. University of Illinois.

Pro-Posições, Campinas, v. 20, n. 2 (59), p. 225-252, maio/ago. 2009 
Château de Pagny. 0 políptico em questão tinha sido adquirido para essa mesma capela durante a sua reforma nos anos 30 do século XVI ${ }^{28}$.

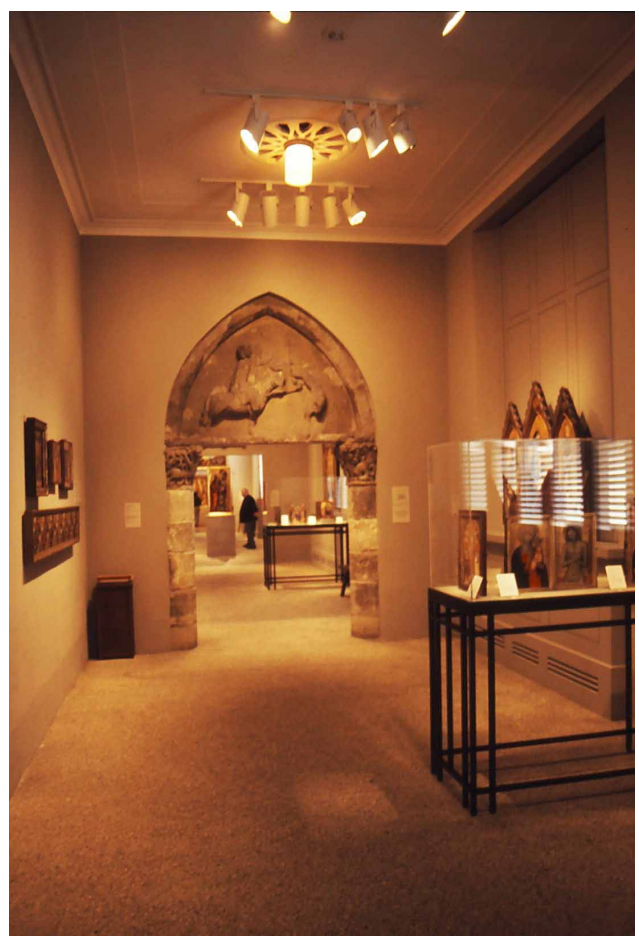

Fig. 13: Philadelphia Museum of Art, Gallery 210, "Early Italian Painting"

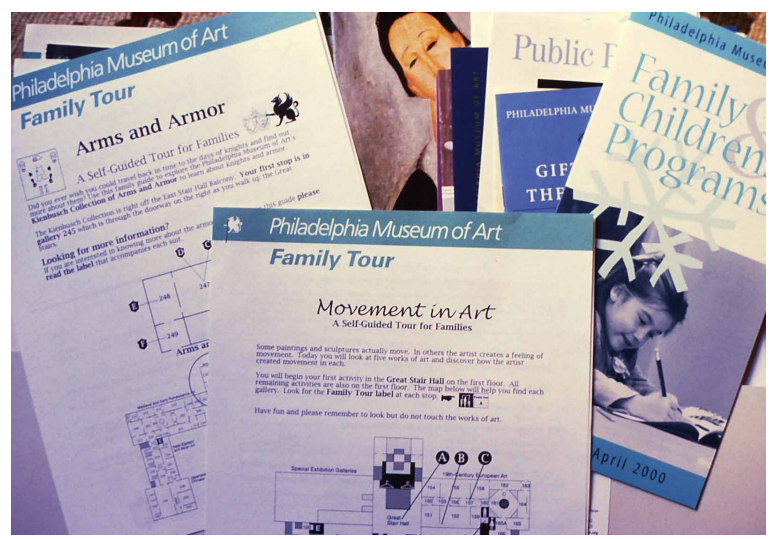

Fig. 14: Materiais pedagógicos do Philadelphia Museum of Art.

28. Cf. Philadelphia Museum of Art. Handbook of the collections, fichas nas páginas I 24 e 125.

Pro-Posições, Campinas, v. 20, n. 2 (59), p.225-252, maio/ago. 2009 
Esses poucos exemplos tornam evidente que é dada muita atenção aos aspectos funcionais das obras. Às vezes a iconografia se impõe. Pouco se diz ou se faz, entretanto, nas cards, para explorar os problemas próprios da pintura, a sua linguagem específica, a expressão. É o caso de dizer, porém, que as "funções", pelo menos no que diz respeito aos retábulos, aos polípticos e a muitos elementos arquitetônicos, são, talvez, mais familiares para o público europeu, acostumado a ver quadros e afrescos nas igrejas, nos claustros de todas as épocas - em suma, nos lugares aos quais eram destinados originariamente e, obviamente, nos museus -, do que para o público americano ${ }^{29}$.

A aproximação à linguagem artística propriamente dita ocorre, no Philadelphia M useum of Art, por outros canais. A oferta de cursos, laboratóriOS, encontros, one day workshops, para todas as idades e exigências, é muito rica e não seria possível descrever, aqui, todas as atividades. Todavia, três iniciativas aparentemente simples e complementares entre si merecem ser comentadas. Elas são exemplos de atuação didática bem-sucedida do museu. Trata-se dos programas "D rawing together" e "Try a Tecnique" e dos guias impressos "Family Tour". No primeiro caso, pessoas de todas as idades e as famílias podem, orientadas por um artista, praticar o desenho. No período compreendido entre janeiro e abril de 2000, a atividade foi realizada em três domingos de cada mês. I sso acontece no próprio espaço do museu - os amplos terraços internos que, do segundo andar, dão para a "G reat Stair H all" são ideais para esses encontros. 0 horário estabelecido é das 12 às 14:30 horas. Levando-se em consideração que, aos domingos, a entrada é gratuita das 10 às 13 horas; que, para essa atividade, o material é fornecido pelo próprio museu; e que não é cobrada nenhuma taxa de inscrição, não é difícil imaginar a sua popularidade. D essa forma, paral elamente aos cursos mais estruturados - pagos -, o museu oferece, de qualquer maneira, uma aproximação guiada ao desenho.

A segunda atividade, "Try a Tecnique", como o próprio título indica, foi concebida para responder à pergunta: "C omo o artista fez isso?". É uma verdadeira atividade de laboratório, na qual as crianças de 6 a 13 anos e os adultos que as acompanham aprendem os métodos usados pelos artistas e experimentam as técnicas em primeira pessoa. No dia 9 de janeiro de 2000, a técnica enfrentada era o mosaico. Em outro encontro, no dia 13 de fevereiro do mesmo ano, o tema explorado eram os tabuleiros dos jogos de mesa. A admissão

29. É preciso não esquecer que, nos Estados Unidos, desde a sua colonização, domina uma religião iconoclasta, o Protestantismo. Por isso, a arte ocidental, que, da Idade Média ao século XVIII, teve a Igreja Católica como um dos seus principais mecenas, foge freqüentemente à compreensão dos não católicos no que diz respeito a muitos dos seus temas figurativos e às suas funções rituais. No caso dos países europeus "reformados" (ou parte deles), o mecenatismo eclesiástico cessou somente nos Quinhentos, deixando, de qualquer forma, uma história atrás de si. 
nesses workshops é limitada e prevê o pagamento de uma pequena taxa para cada criança inscrita e a participação gratuita dos pais. A terceira proposta são as visitas auto-guiadas (self-guided tours) para as famílias. Todos os dias, 0 Philadelphia M useum of Art coloca à disposição dos interessados, gratuitamente, uma série de impressos com o nome de "Family Tour"30. São como apostilas que contêm uma página de abertura, na qual é proposto um tema e 0 mapa do museu, com a indicação das salas onde se encontram as obras a serem vistas, e, nas páginas seguintes, questionários e desenhos concebidos para chamar a atenção para um ou mais aspectos das obras assinaladas. No mês de março de 2000, três temas estavam disponíveis: "M ovement in Art", "Arms and Armor" e "Winter Wonderland".

"M ovement in Art", como o próprio título dá a entender, explora o tema do movimento na escultura e na pintura. Propõe-se a observação e a exercitação em torno de cinco obras na seqüência seguinte: "G host", o grande móbile de Alexander Calder que pende do alto do teto do grande saguão do museu; a escultura "Bailarina de catorze anos", de D egas (sala 152); "D ança no Moulin Rouge", de Toulouse-Lautrec (sala 157); a "Roda de bicicleta", de $\mathrm{M}$ arcel Duchamp (sala 182); e, ainda do fundador do dadaísmo, a tela "N u descendo uma escada ( $n^{\circ} 2$ )" (sala 182). Para cada uma das obras envolvidas, é chamada a atenção para um el emento que provoca a sensação de movimento - ou, no caso específico do móbile de Calder, tenta-se fazer com que o visitante entenda, sem, aliás, dar-Ihe a resposta pronta, por que "G host" se move realmente. $\mathrm{Na}$ conclusão do questionário sobre o "Nu descendo uma escada" de D uchamp - obra que propõe, numa visão simultânea, a seqüência de vários movimentos de uma figura -, a criança, o adolescente e os adultos são convidados a desenhar, no espaço em branco deixado na última página, três figuras, uma sobre a outra - a primeira, parada; a segunda, levantando uma perna; e a terceira, dando um chute - , com o objetivo de fazêlos entender, a partir da própria experiência, como D uchamp obteve a sua imagem do movimento.

Poderíamos perguntar-nos: por que não envolver obras de outros períodos no discurso sobre o movimento? Por que não mostrar que pode haver movimento também na representação de figuras paradas (o célebre movimento in potenza, de $M$ atteo $M$ arangoni ${ }^{31}$ ). Por que não indicar, na tela de Toulouse-

\footnotetext{
30. O Hirschhorn Museum and Sculpture Garden, em Washington, também fornece, a pedido, um "Family Guide" para a visita auto-guiada, que os adultos podem utilizar para introduzir as crianças à arte moderna e contemporânea.

31. No seu livro Saper vedere (Milano, Vallardi, 1986; p. 224-264), Marangoni explica como a expressão de movimento não depende da representação de uma figura no ato de realizar um movimento, mas do movimento potencial das linhas, das cores e de tudo o que compõe a imagem, inde-
} 
Lautrec, como se pode criar a sensação de movimento simplesmente com a linha, independentemente da cena representada? N essas propostas - como já foi evidenciado no caso das folhas didáticas da Pennsylvania Academy of the Fine Arts - procura-se envolver o visitante, fazendo, constantemente, alusão à vida real. Raramente, procura-se levá-lo a um raciocínio mais abstrato, menos vinculado ao cotidiano. $\mathrm{N}$ ão se usam nunca desenhos abstratos, ainda que simples e compreensíveis a todos, para mostrar de que forma uma simples linha que não representa nada pode, entretanto, expressar o movimento, a estaticidade, dar a sensação de um plano estável, do movimento fluido ou sincopado, como demonstra Paul Klee no seu memorável Paedagogisches Skizzenbuch (C aderno de desenhos pedagógicos). Freqüentemente, as fichas terminam um pouco antes de fornecer os instrumentos que são a chave para entrar no universo do artista e das suas obras, no mundo da linguagem específica das artes.

De qualquer forma, estas três propostas fornecem uma dupla experiência da arte: uma prática e outra interpretativa. Evitando o enfoque "nocionista" ou seja, o das definições já prontas, que não fornecem os instrumentos da experiência -, elas tendem uma mão aos outsiders, ao público não iniciado desejoso de familiarizar-se com a arte e a sua história. São um primeiro passo. $M$ ais tarde, o visitante, conquistado pela arte, voltará para aprofundar a sua relação com o museu e descobrirá pouco a pouco toda a complexidade da disciplina.

No percurso através dos museus de Filadélfia, omitimos muitas instituições, como o Museu de Arqueologia e Antropologia da Pennsylvania University - com o qual tínhamos aberto este relatório -, o Franklin Institute Science M useum e a Academy of $\mathrm{N}$ atural Sciences. Cada um deles participa ativamente do determinado empenho pedagógico que distingue os museus da cidade. Assim como participam, também, o M useu Rodin - que, apesar de ter uma sede separada do Philadelphia M useum of Art, é uma extensão dele e o projeto pedagógico e social verdadeiramente interessante do Samuel S. Fleisher Art M emorial, que conjuga educação artística, experimentação, divulgação do trabalho dos artistas jovens da cidade, num espaço composto, além das salas para as exposições temporárias, dos escritórios e do ateliê, por uma igreja insólita, de um estilo entre neo-românico e neogótico senês, com

pendentemente da ação imediata. Assim, existe um movimento in potenza, que pode caracterizar, também, uma figura sentada ou aparentemente estática. Vice-versa, uma figura correndo ou realizando um movimento qualquer, o movimento in azione, pode parecer estática se não for dotada, também, de movimento in potenza. Na arte, o movimento não é uma propriedade da figura que realiza uma ação, mas sim das linhas, dos relevos, das cores: ele pode existir independentemente da figura e da própria ação. 
uma coleção de esculturas medievais, e por uma sala didática experimental dedicada ao célebre arquiteto de Filadélfia, Louis Kahn ${ }^{32}$.

O s cursos de longa duração, os ciclos de conferências, os concertos, a projeção de filmes são atividades comuns a muitos museus americanos e não americanos. Ao contrário, o fervor pedagógico generalizado, expresso na qualidade, na quantidade e na constância dos materiais colocados à disposição do público, parece ser um traço museológico específico da cidade da "amizade fraterna". Fornecer mais exemplos - e seria possível incluir ainda muitos - parece-nos, todavia, supérfluo. O s exemplos ecolhidos demonstram amplamente que a museologia, como é praticada em Filadélfia, desempenha plenamente o papel de divulgação cultural e de promoção social que, pelo menos na teoria, marcou o nascimento do museu moderno nos tempos da Revolução Francesa.

32. Parece ir contra corrente, nessa tendência generalizada à ação pedagógica de amplo alcance, a Barnes Foundation. Segundo Kimberly Camp, sua diretora no período em que foi realizada esta investigação, uma interpretação restritiva demais, nas últimas décadas, do testamento do Dr. Albert Barnes reduziu a atividade da fundação somente aos cursos fechados de três anos de duração. Excluindo-se os cursos, - que, conforme o método preconizado por Barnes, realizamse exclusivamente em contato direto com as obras e aos quais é reservado o uso exclusivo das salas do museu quatro dias úteis por semana -, a Barnes Foundation abre suas portas ao público somente às sextas, aos sábados e aos domingos e é necessário reservar. Para o visitante comum, pelo menos até o final de março de 2000, não era previsto nenhum material pedagógico. 